\title{
Audiovisual aUtORAL e O ROTEIRO MULTIDIMENSIONAL NA PRODUÇÃo dO DOCUMENTÁRIO
}

Ariane Daniela Cole Instituto Presbiteriano Mackenzie ${ }^{1}$

Buscamos desenvolver uma análise sobre o processo de realização, do documentário "Evandro Carlos Jardim, Nas Margens do Tempo", sobretudo no que diz respeito ao processo de roteirização. Este documentário apresenta a obra de Evandro Carlos Jardim, artista plástico e gravador brasileiro, que hoje conta com 50 anos de produção integra e ininterrupta, tanto como artista quanto como professor. Além de lidar com este universo, tão extenso quanto profundo, outras complexidades se apresentaram como grandes desafios, como por exemplo, abordar seu trabalho e as questóes provenientes de sua obra, constituída de imagens, através da linguagem audiovisual; o registro do espaço e do tempo, dos seres e objetos que o habitam; a narrativa; o gesto; o texto; a oralidade; a música e a poesia. Objetivamos refletir sobre os seus objetivos, escolhas e seus desdobramentos formais, éticos e estéticos.

Palavras chave: documentário, arte, linguagem audiovisual, roteiro

\section{INTRODUÇÃO}

Analisar o processo de realização do documentário Evandro Carlos Jardim, Nas Margens do Tempo, de minha autoria junto a Artur Cole, fruto de pesquisa intitulada $A$ Poética de Evandro Carlos Jardim. Figuras: seres, tempos e lugares, sobre a obra de Evandro Carlos Jardim, artista brasileiro que hoje conta com 50 anos de produção, tanto como artista quanto como professor, nos levou a refletir sobre a produção de documentários de um modo mais abrangente. Além de lidar com este universo, tão extenso quanto profundo, outras complexidades se apresentaram como grandes desafios, como por exemplo, abordar seu trabalho e as questões provenientes de sua obra, constituída de imagens, através da linguagem audiovisual; o registro do espaço e do

1 A pesquisa intitulada "Figuras: seres, tempos e lugares" deu origem ao documentário em questão, e recebeu apoio do Mackpesquisa do Instituto Presbiteriano Mackenzie. 
tempo, dos seres e objetos que o habitam; a narrativa; o gesto; o texto; a oralidade; a música e a poesia.

A obra de Evandro Carlos Jardim se constrói de modo integrado, ao longo do tempo, desde a década de 1960, coletando imagens em sua vivência da cidade de São Paulo, a partir do interior de seu atelier, ponto de partida e de chegada. Os seres e objetos que habitam estes espaços constituem uma espécie de dicionário visual imaginário, sensível, carregado de história, de memória, nos estimulando à reflexão sobre a técnica, a cultura e a história, nos conduzindo ao centro de sua obra.

Estas poucas imagens, sempre recorrentes, foram inicialmente recolhidas entre as décadas de 60 e 70 e constituíram um conjunto de 20 imagens elaboradas no processo de criação da série $A$ noite no quarto de cima, o Cruzeiro do Sul, latitude 2332‘36”, longitude W Gr. 46 37’59”, coordenadas geográficas que situam a localização de seu antigo atelier. Por volta de 1963, Jardim passou a organizar suas gravuras em séries, estas foram a partir de então desenvolvidas simultaneamente. Não há um começo e fim definidos e hoje este acervo conta com aproximadamente 60 imagens.

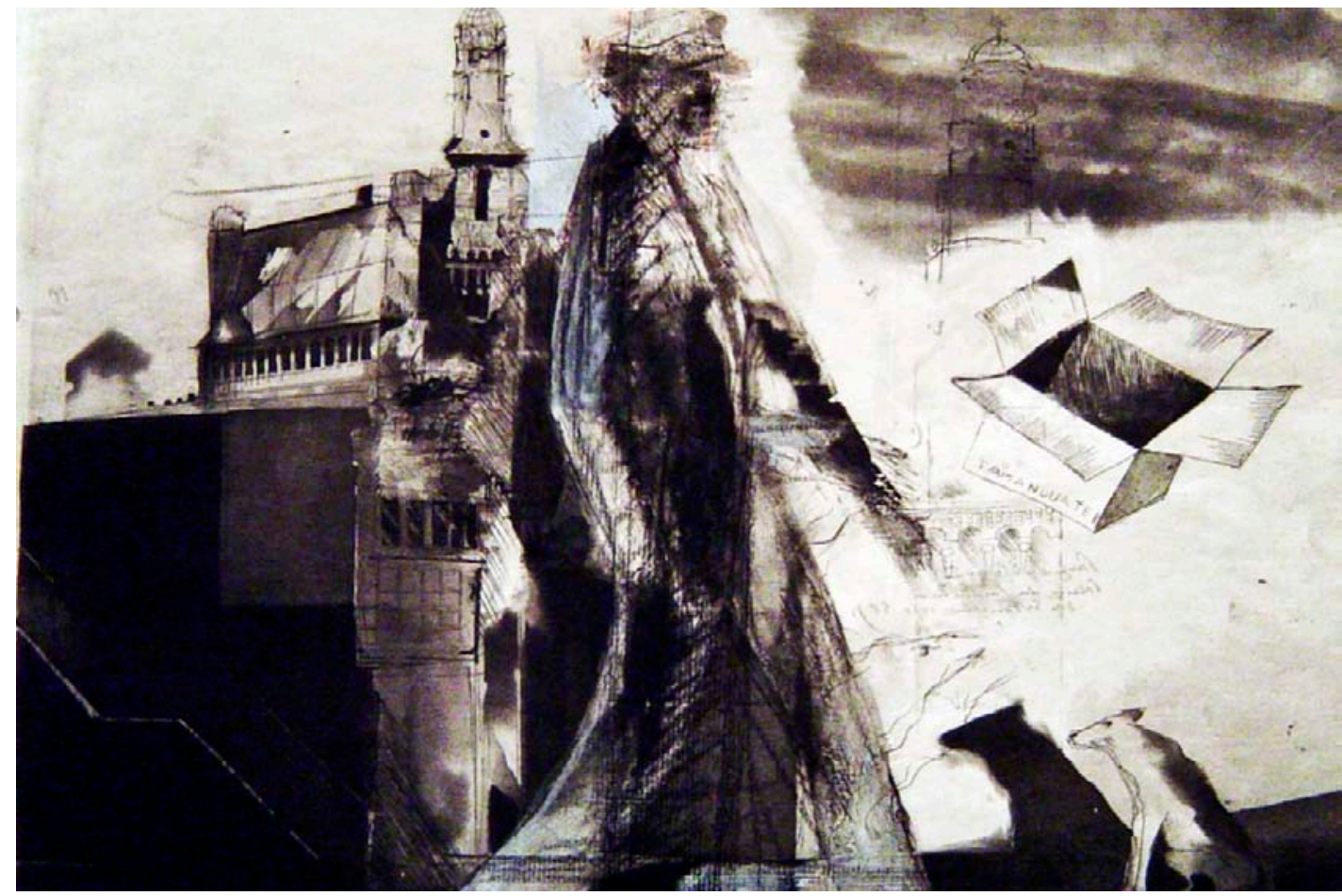

Figura 1: Gravura da série Tamanduateí (1980). Água-forte, água tinta e buril sobre papel. 29,5 x 50 $\mathrm{cm}$.

Seu ateliê como centro de um círculo imaginário, espaço real, e ao mesmo tempo espaço ilimitado do imaginário do artista, veio a ser desde então, a fonte visual que alimenta seu repertório poético. Caminhar pelos lugares, desenhando em seus cadernos e matrizes impressões e sensações, e em seu seu ateliê registrá-las em desenhos e gravuras, faz parte de sua prática corrente. Ao buscarmos refazer o percurso de Jardim, descobrimos que, justamente por ser imaginário, o diâmetro desse círculo é insondável.

Assim, podemos observar em sua poética a importância fundamental da memória e 
do tempo. Esta trajetória confere à sua obra um caráter que abriga componentes narrativos, densidade conceitual e identidade formal, o que favorece uma aproximação com sua obra como um todo através da linguagem audiovisual.

$\mathrm{Na}$ composição de suas séries, o artista transita entre diferentes técnicas como desenho, o recorte, a gravura, a pintura e a escultura, entre outros procedimentos; faz uso de recursos como raspagens, inclusões de novas imagens, alteração do desenho em uma mesma matriz de cobre, gerando diferentes estampas. ${ }^{2}$

Evandro Carlos Jardim recupera imagens, cenas e personagens do dia a dia da cidade de São Paulo. Resgata e conduz nosso olhar para nossa própria história, aqui simbolizada pelo que é comum a todos, a cidade. Um espaço carregado de marcas/marcos testemunhos da história do homem. Seu objetivo não é retratar a paisagem real, mas recompô-la e transfigurá-la para promover e aprofundar o entendimento da realidade (Fig. 1).

As figuras recorrentes em sua obra não são apenas estratégias estéticas, sintetizam sua poética. Quando Jardim nos reapresenta suas imagens, está nos convidando à refletir sobre a permanência das coisas, suas relações com o contexto, suas múltiplas e sutis transformações de suas aparências, as questões sobre a representação e suas construções simbólicas, abrindo inúmeras possibilidades de interpretação.

Ao aprofundarmos nosso contato com o artista Evandro Carlos Jardim e o conhecimento sobre sua obra pudemos observar seu entendimento, da técnica, da construção do conhecimento, da constituição da cultura, sua noção de história, a importância da arte nestes processos. Para Evandro Carlos Jardim o conceito de técnica não deve ser reduzido, ou confundido com seus procedimentos, necessários. Técnica ao seu ver é fruto de processos de criação, pressupõem conhecimento, história, cultura.

Junto aos seus ex-alunos e interlocutores pudemos observar o quanto sua poética se desdobra para além de sua obra, na sua atuação como educador, formador de toda uma geração de artistas brasileiros e em suas ações como ser.

A obra de Evandro apresenta, enfim, dimensões sobrepostas a partir da qual o observador pode se aprofundar e desvendar sua densidade. ${ }^{3}$ A sua obra exige um esforço, sobretudo uma disponibilidade, para a sua apreciação estética onde a imagem não quer apenas mostrar sua aparência, nos fala de estética, de técnica, nos fala da percepção, da imaginação, da natureza, do tempo/ espaço e dos seres que os habitam.

Partimos assim da idéia de produzir uma homenagem a este grande mestre, de um desejo de expressão, da intenção de produzir reflexões, emoções, proporcionar experiências estéticas, da importância de difundir o conhecimento sobre sua obra e ao mesmo tempo agregar seus ensinamentos na constituição do próprio documentário.

2 Alguns exemplares de sua obra, apresentando este procedimento, encontram-se em fragmento do documentário disponível em <http://vimeo.com/32621992> com o título "Evandro Carlos Jardim. Nas Margens do Tempo_Figuras Jacentes".

3 Fragmento do documentário em < http://vimeo.com/32621992> com o título "Evandro Carlos Jardim. Nas Margens do Tempo_Do_Desenho”. 


\section{ROTEIRO EM MOVIMENTO}

De modo geral, sobretudo em filmes de ficção, um filme se constitui a partir da elaboração de um roteiro. Entretanto este procedimento varia bastante sobretudo no que se refere à produção de documentários. Vimos ao longo da história e ao longo do desenvolvimento das técnicas a adoção de diversos modos de construção de filmes, sejam artísticos, de ficção, documentários ou filmes científicos, cada qual, ao seu modo, portadores de uma concepção de realidade.

Sabemos que um roteiro, fixado afinal no filme sobretudo na produção de documentários, se constrói a cada etapa do processo, adquirindo diversas faces ao longo de todo o processo, da pesquisa à finalização.

Para Vertov a montagem se dá já na escolha de um tema, dentre inúmeras possibilidades de temas possíveis, se dá quando ele faz observações, recortes e sínteses sobre o seu tema, quando estabelece uma seleção, um ordenação, uma configuração para o material recolhido entre tantas possibilidades, considerando tanto as propriedades do material filmado quanto priorizando a temática elegida. (Xavier 1983).

Em nossa experiência vimos o roteiro adquirir materialidades diversas a cada momento, sendo que o primeiro roteiro já se apresentava na estrutura da própria obra de Evandro Carlos Jardim. Partimos inicialmente de um conjunto de palavras pinçadas no processo de pesquisa e análise de sua obra. Neste momento o roteiro, uma composição de palavras associadas, se apresentava como um mapa que possibilitava inúmeros percursos (Fig. 2).

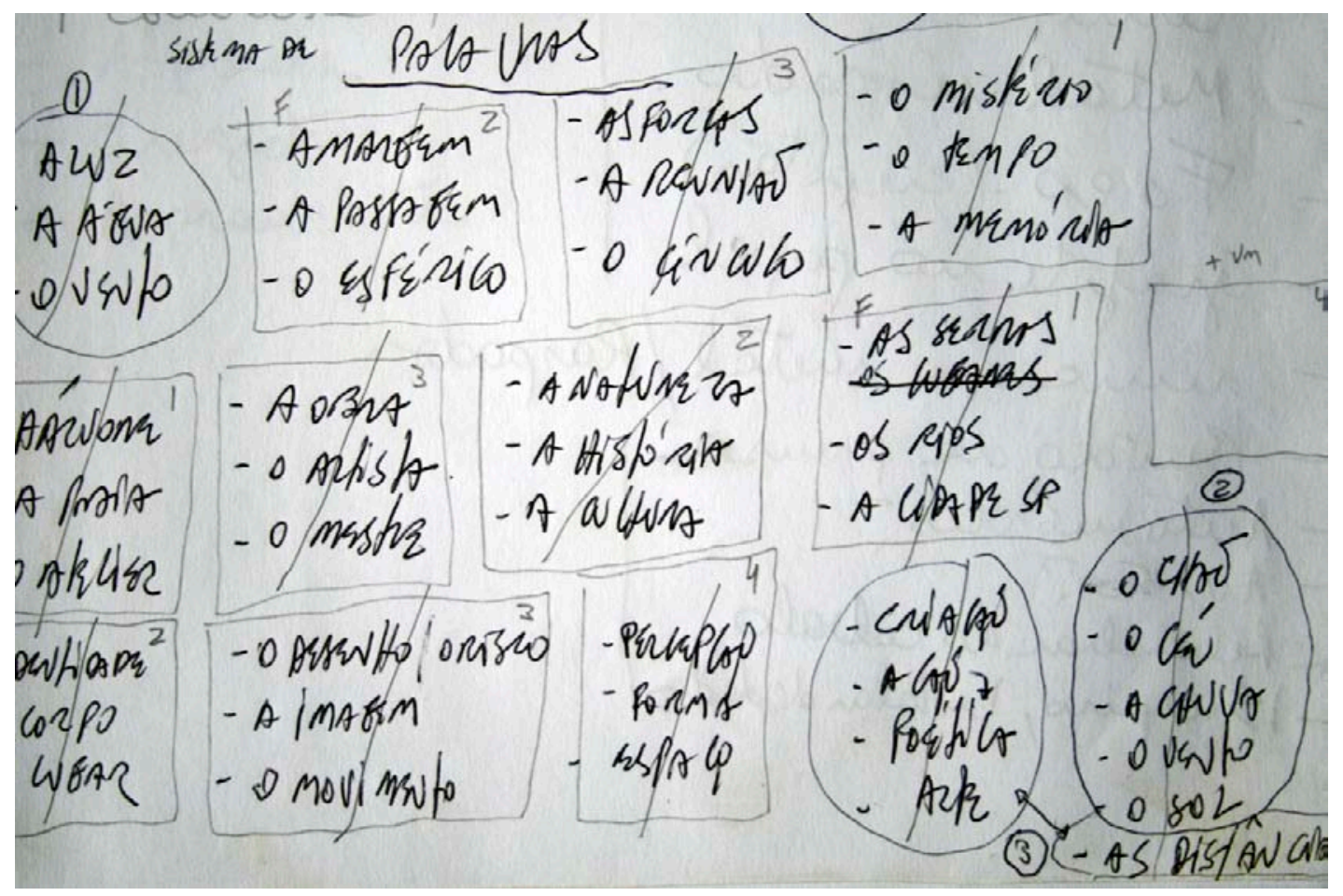

Figura 2: Mapa de palavras.

A partir das palavras chave, do conhecimento do artista e da sua obra idealizamos uma primeira estrutura de roteiro. Desta estrutura inicial, mantivemos muitas das temáticas, mas o 
único elemento que se manteve, em sua integridade, foi o plano final do vídeo, que se tornou elemento referencial importante na construção do roteiro.

Consideramos então a possibilidade de abordar sua obra em seu processo de constituição e então estabelecemos uma seqüência de blocos de abordagem, que nos serviu de guia para o cronograma de captações.

Neste estágio o roteiro já assumia a forma de uma estrutura. No primeiro bloco abordaríamos as origens de sua poética, tendo como centro o seu atelier antigo e seus elementos orbitantes. $\mathrm{O}$ segundo bloco se dedicaria ao seu trabalho e seu atelier atual. O terceiro bloco abordaria a sua ação como professor e encerraríamos com uma visita à nascente do Rio Tamanduateí, referência importante em sua obra.

Entretanto, ao aprofundarmos o contato com sua obra percebemos que tanto o espaço como o tempo, em sua obra, são insondáveis, não se permitem delimitar e se interpenetram em camadas de adensamento.

A experiência da filmagem, bem como o contato com o universo abordado, pode subverter as noções preliminares, esboçadas na pré-produção, criando novos focos de interesse para o filme, o que obriga, ao realizador, pensar nova organização do material, que incorpore estas mudanças (Puccini 2009:101).

Deste modo optamos por realizar um documentário de natureza exploratória, partindo de dois princípios básicos da linguagem audiovisual, o plano e a montagem, estes nos serviram de parâmetro, no sentido de indagar sobre alguns procedimentos, e as opções metodológicas adotadas.

Deleuze (2007) identifica, na construção cinematográfica, a importância tanto do plano quanto da montagem desenvolvendo uma análise mais aprofundada de cada um destes elementos tão fundamentais na constituição de um filme. Para o autor, podemos distinguir entre as imagens-movimento, três categorias de imagens, imagens-percepção, imagens-afecção e imagens-ação, sua integração compõe o que ele chama de imagem-relação, que se funda nas relações seja entre a percepção, a afecção, e a ação, seja em relação ao tempo da imagem, ao sujeito ou objeto com o qual ela se relaciona.

A imagem-movimento tem duas faces, uma em relação a objetos cuja posição relativa ela faz variar, a outra em relação ao todo cuja mudança absoluta ela exprime. As posições estão no espaço, mas o todo que muda está no tempo. (Deleuze 2007:48).

$\mathrm{Na}$ experiência de estabelecer uma relação entre a câmera e um artista, operamos a princípio com estas suas duas dimensões da linguagem audiovisual: o plano e a montagem. Considerando o planos em suas possibilidades perceptivas, afetivas e conceituais, assim como a construção do discurso através das relações que pudemos estabelecer entre as imagens, entre as imagens e seus sujeitos e objetos e as suas abordagens.

\section{Do Plano}

Para Munstemberg tudo o que afeta nossos sentidos, provocando emoções, assume forte controle de nossa atenção (Xavier 1983). Neste sentido o enquadramento é elemento 
fundamental na constituição do plano. No cinema basta a eloqüência de um close e não são mais necessários gestos ou palavras.

Griffith foi o primeiro cineasta a perceber as potencialidades do close pois este mostranos a face das coisas as nossas expressões nelas impregnadas revelando substratos de nossa subjetividade. Balázs refere-se à potencialidade do close para nos despertar a emoção, para ele o bom close nos faz ver com o coração, não com os olhos. A câmera cinematográfica nos apresentou um novo mundo, um mundo onde se revela a face humana, a alma dos objetos, o ritmo dos eventos. Mesmo que sentados em uma poltrona, não é de lá que assistimos aos eventos, a câmera nos carrega para dentro do filme, os nossos olhos se encontram na objetiva da câmera. Neste sentido o enquadramento é um dos elementos primordiais na construção de um filme (Xavier 1983).

Pudemos observar no processo de aproximação com Evandro Carlos Jardim que o vídeo se constrói também utilizando muito da expressividade dos planos, utilizamos assim planos mais abertos para expressões verbais mais objetivas e planos mais fechados para expressividades que implicavam de modo mais intenso a subjetividade, a abstração e a emoção.

Béla Balázs reafirma a importância da subjetividade desvendada pela câmera. Segundo ele, a imagem, o gesto, a expressão facial é a "língua mãe aborígene da raça humana", que a palavra não pode traduzir. Para ele o gesto possibilita a comunicação de conceitos que não podemos expressar através das palavras, emoções que não podemos racionalizar (Xavier 1983).

Deleuze (2007), ao se referir sobre as distinções entre objetividade e subjetividade de uma câmera, observa que é justamente a impossibilidade de fazer estas distinções que a torna instigante, questionante, capaz de nos despertar tanto a emoção quanto nosso intelecto ou nossa psique.

Esta capacidade do cinema, de revelar o indizível, permite a apreensão do gesto do olhar, das palavras nas mãos, das paisagens nos rostos, das narrativas que se desenvolvem no entrecruzamento das várias linguagens que habitam o audiovisual. A produção de um documentário que registra pessoas, que depõem sobre suas experiências, através de longas exposições nos leva à noção do retrato. A longa exposição necessária para a realização de retratos em pintura, ou nos primórdios da fotografia, revelam a importância do tempo como princípio de sua constituição pois fazem emergir os traços essenciais de um rosto. Este tempo alargado possibilita ao retratado que exponha sua expressão mais eloqüente, para que o espectador possa captar sua dimensão densa, sagrada, trata-se de buscar uma ética do olhar "É preciso ter tempo para ver rostos e paisagens. Para se evidenciarem a força e a atmosfera que deles emanam. $\mathrm{O}$ drama interior das pessoas, a serenidade dos lugares. Tudo aquilo que não se estampa de imediato" (Brissac Peixoto 1992:304)

A comunicação através da expressão corporal não obedece a regras rígidas tal qual a gramática ou a filologia, ela não se aprende em escolas, entretanto é capaz de se dirigir aos nossos afetos, esta é uma das razões de sua universalidade. Esta era para Balázs uma das grandes contribuições do cinema para o desenvolvimento do homem universal. O filme carrega esta capacidade de engendrar imagens-percepção capazes de agregar tanto a percepção do cineasta como a do espectador, imagens-afetivas e afetantes, imagens-ação seja ele executado pelo ator, pelo cineasta, ou ainda pelo espectador que hoje tem acesso aos meios de produção e difusão. 
De acordo com a psicologia e a filologia, os sentimentos se definem na medida em que podemos expressá-los, assim como acontece com as palavras que favorecem a criação de conceitos e sentimentos, também a expressão do corpo favorece o desenvolvimento sensível e a capacidade de comunicar potencializa-se. $\mathrm{O}$ acréscimo do som agrega novas dimensões comunicativas através da palavra, da música ou dos ruídos. Se por um lado estas novas dimensões podem diluir a força da expressão facial elas podem torná-la, por outro lado, ainda mais complexa desvendando estratos mais profundos e intrincados da emoção humana, e ao invés de promover um nivelamento, promove uma multiplicidade de expressões e um entendimento mais aprofundado de uma gama mais ampla de manifestações culturais e emocionais.

Nas gravações buscamos registrar um encontro, uma conversa, o depoimento no lugar da entrevista, sempre no sentido de aprofundar os conceitos, idéias e emoções que se apresentavam, deixando o espaço aberto para que cada um se manifestasse à sua maneira, deixando o pensamento correr livre, esperando a pausa acontecer para sugerir novas abordagens, suscitando maiores reflexões, para depois selecionar.

Como, ou sobretudo porque, éramos uma equipe de pesquisadores, adotamos a posição dos interlocutores atrás das câmeras o que gerou, mesmo que de modo indireto, uma câmera subjetiva para o espectador, no sentido de valorizar a presença do artista, colocando o espectador na posição de um dos interlocutores, convidando-o a participar daquele momento, daquele contexto, espaço/tempo e do desenrolar das reflexões.

\section{IMAGEM RELAÇÃo}

Segundo Aumont (1994) podemos apreender dois elementos da montagem: o objeto sobre o qual a montagem opera, ou seja, os planos, cenas e seqüências e as modalidades de ação da montagem que determinam as sucessões destes objetos de acordo com critérios vinculados à ordem e à duração. Sobre estes dois elementos da montagem incidem três modalidades de operação de justaposiçẫo que irá determinar como um plano se liga a outro.

Com estes três tipos de operação - justaposição (de elementos homogêneos ou heterogêneos), organização (na contigüidade ou sucessibilidade), fixação da duração - mostramos todas as eventualidades que encontraremos (e, o que é mais importante, todos os casos concretos praticamente imagináveis e atestáveis) (Aumont 1994:62).

Desdobradas as operações que constituem a montagem, devemos agora considerar os resultados expressivos que podemos obter com estas operações, quais as funções que a montagem pode assumir na construção de um filme.

Numa análise mais sistemática, Aumont (1984) nos apresenta a noção de "montagem produtiva ou criativa" cuja função primordial é criar uma significação a partir da justaposição dos planos que isoladamente não possuem este significado.

Desdobrando a montagem criativa podemos identificar funções de naturezas diferentes. As "funções sintáticas" que pontuam, ligando ou separando os planos, criando efeitos de alternância, paralelismos, simultaneidades. As "funções semânticas" responsáveis pela criação de significados a partir da justaposição dos planos e as "funções rítmicas" que podem ser definidas 
pelos "ritmos temporais" através da trilha sonora, os dos movimentos visuais e pelos "ritmos plásticos” definidos pela organização da imagem.

Para a realização deste documentário buscamos adotar a montagem criativa descrita acima por Aumont (1984). Podemos identificar esta intenção nas inserções de imagens que atuam como elementos que integram os planos, enriquecendo-os e aprofundando nossa percepção, afeto, nosso intelecto e assim apresentam uma função imprescindível na montagem.

Assim como Eisenstein, Deleuze (2007) propõe que o todo alcançado pela montagem não é resultado de uma mera justaposição ou sucessão de presentes, ela deve operar pela alternância de conflitos, ressonâncias, pela coexistência de tempos, passado e futuro incorporados ao presente, que por sua vez, é resultado de toda uma atividade de seleção e coordenação, "para dar tanto ao tempo sua verdadeira dimensão, quanto ao todo sua consistência” (Deleuze 2007:48).

\section{ROTEIRO MULTIDIMENSIONAL E MONTAGEM}

Sabemos que a realidade, no caso da produção de um documentário, nos escapa o tempo todo, não se deixa abarcar, nem moldar, apresenta as suas fissuras, falhas, oscilações, surpresas, exigindo do realizador uma atitude criativa ininterrupta, já que, sabemos, não é possível representar a realidade sem a intervenção de nosso olhar. Ao inserir o ato criativo na abordagem de nosso assunto e na montagem, agregamos as posturas da investigação, da experimentação e da invenção.

Optamos assim pelo desenvolvimento de um trabalho de captação de caráter exploratório, por uma montagem criativa. Assim, evitamos encontros prévios com os artistas que participariam do vídeo, interrupções nos processos de captação de imagens, priorizamos uma movimentação discreta da câmera no sentido de garantir a espontaneidade do momento, momento este que, sabemos, nunca se repetirá. Deste modo, trabalhamos na medida do possível com mais de uma câmera. Também buscamos colher imagens dos espaços onde estivemos, agora com uma movimentação mais livre da câmera, antes e depois dos depoimentos, buscando colher imagens eloqüentes que pudessem revelar novas dimensões significativas na construção do vídeo.

Se em um filme de ficção o controle da realização está, de saída, estabelecida pelo roteiro elaborado antes do processo de captação das imagens, em um documentário este controle se dá de modo gradual e apenas se estabelece na sala de montagem, com, ao menos, grande parte do material coletado; permitindo ao diretor a coleta de imagens complementares para a sua finalização. Assim, é recorrente o fato do processo do roteirização de documentários, baseados em coleta de depoimentos, se dar no momento da montagem, pois é neste momento que podemos ter uma visão mais panorâmica do que foi dito e o recorte, ou a decupagem, pode ser elaborada tendo em vista, sobretudo, a construção de conteúdos. Sabemos que a montagem permeia todo o processo de produção de um filme, que roteirizamos quando escolhemos nossos interlocutores, quando definimos as locações das tomadas, os planos, as sonoridades, quando interagimos estabelecendo uma interlocução, entre tantas ações que envolvem a realização audiovisual. 


\section{Projeto e Realização}

A densidade dos depoimentos coletados demandaram um trabalho minucioso de decupagem e registro de informações que dizem respeito ao conteúdo, localização e duração do fragmento, apreciações quanto à qualidade das imagens e sons, observações de outra natureza necessárias à pré-visualização do fragmento. Este é um momento que requer um esforço de concentração pois é necessário estar atento para as escolhas que se faz, por exemplo: a forma que adotamos para descrever na ficha de decupagem o que está sendo dito, onde incidirá o corte, que às vezes recai em uma expressão, que por sua vez introduz outro assunto, observar possíveis associações com imagens e os discursos de outros interlocutores, classificar a tomada em sua qualidade gráfica, sonora e conceitual. Para isto é necessário, na maior parte do tempo, ver e rever o material, inúmeras vezes.

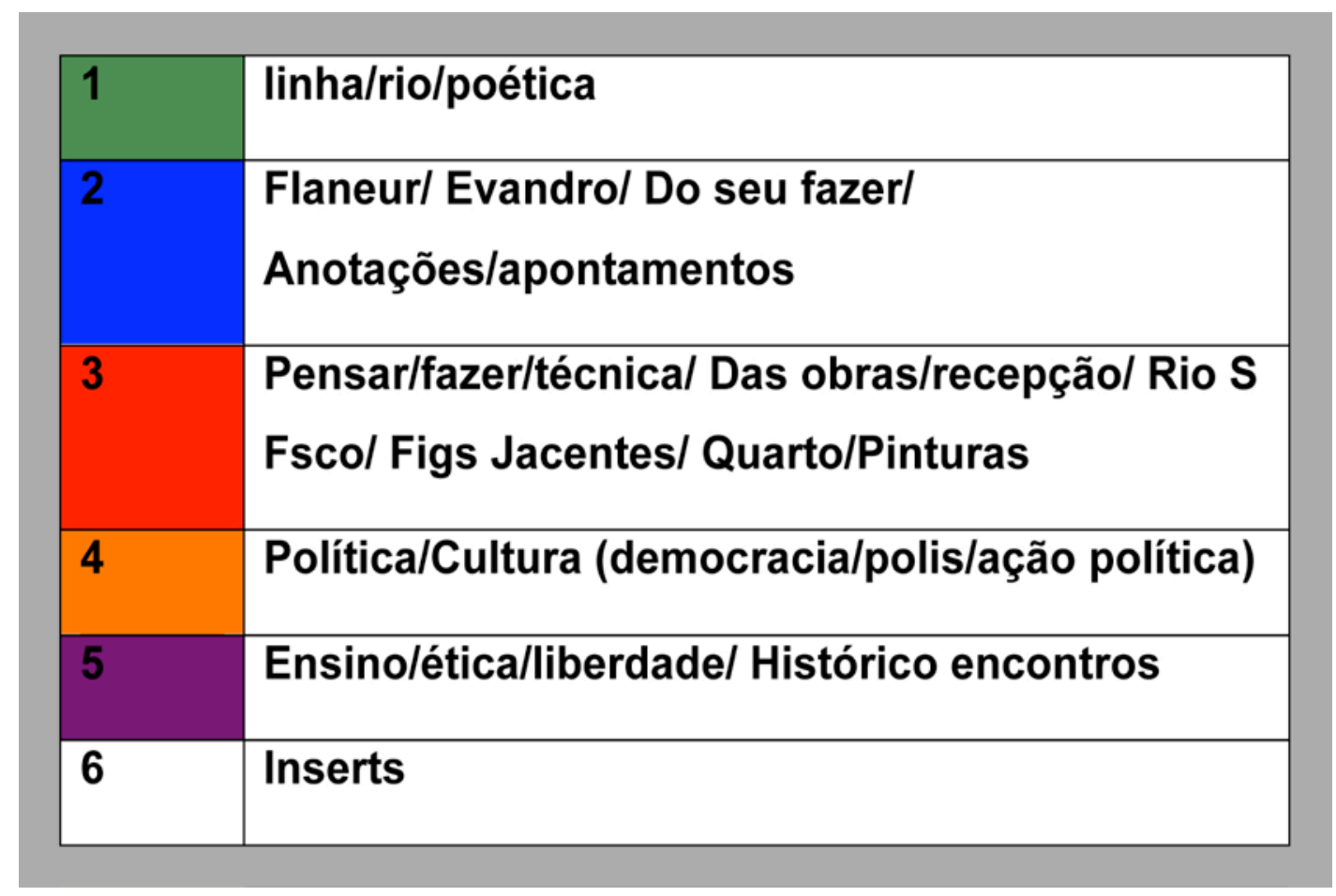

Figura 3: Classificação dos planos.

Ao finalizarmos as gravações e o processo de decupagem, outra forma de roteiro se apresentava. Decidimos estabelecer um método de classificação dos planos, para organizar o material bruto. O método de cartelas coloridas, muito utilizado pelos roteiristas (Field 1975; Rewald 2005; Puccini, 2009), foi adaptado para a realização deste trabalho. A partir das temáticas abordadas pelos artistas identificamos as mais importantes e as classificamos tendo em vista a construção do discurso. Atribuímos assim a cada temática uma cor, considerando este recurso oferecido pela ferramenta de edição de video. Estas temáticas já se aproximavam do que seria a forma final do roteiro (Fig. 3 e 4).

A apresentação das obras tiveram a função, em primeiro lugar, de apresentar a obra de Evandro e também para complementar o que se estava dizendo, nestes casos buscamos sempre, na medida do possível, realizar esta apresentação de modo a proporcionar ao espectador uma experiência estética. 
A seqüência que apresenta uma das gravuras: Figuras I.S. Km 23, sobre o vôo dos pássaros comuns, 1980/19814, busca justamente realizar esta aproximação com a obra de Evandro a partir de uma experiência estética. Seja pela suave e lenta movimentação da movimentação da imagem em plano de detalhe, seja pelo cuidado dispensado à elaboração da música, onde um piano remete à própria árvore em sua generosidade e serenidade, e os violinos remetem ao farfalhar das asas dos pássaros, do frêmito das linhas traçadas em luz (Fig. 5).

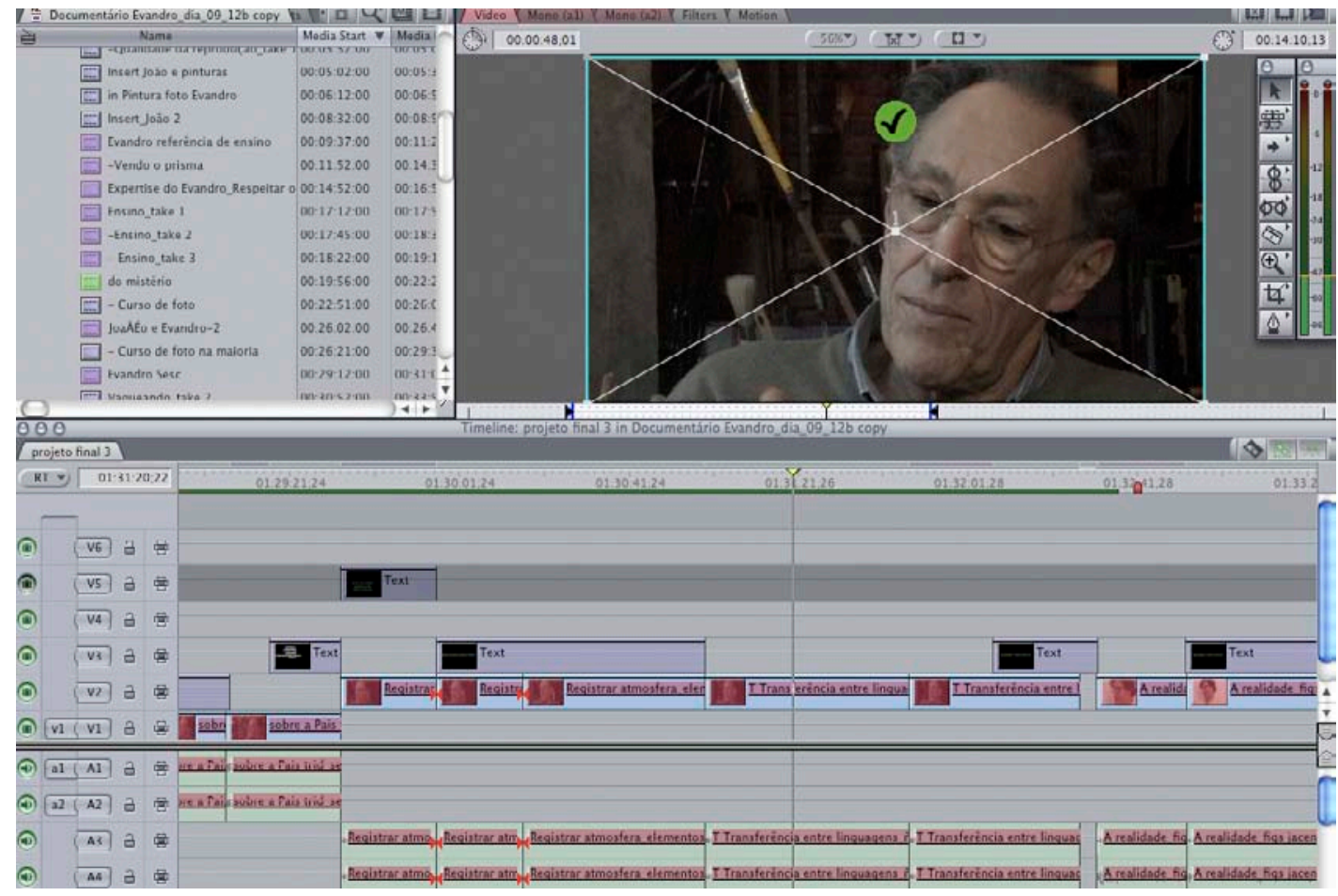

Figura 4. Timeline com clipes classificados por cores.

No final das gravações com todo o material decupado, analisado, classificado e encadeado, realizamos mais uma última tomada no atelier do artista para recolher imagens complementares de sua obra. Nesta ocasião Evandro Carlos Jardim fez um depoimento que iria alterar toda a estrutura do roteiro que se beneficiou destas novas inclusões. A forma final do roteiro, estabelecido na ilha de edição, desenvolve associações entre idéias importantes que permeiam a sua obra. Este se desloca do rio à linha, da linha ao movimento, do movimento à percepção, da percepção à experiência estética, da experiência estética ao desenho, do desenho à forma, da forma à técnica, da técnica à história, da história à cultura, da cultura à política, para ao final retornarmos ao rio em sua origem. ${ }^{5}$

4 Veja seqüência no fragmento do documentário em <http://vimeo.com/32621992> com o título "Evandro Carlos Jardim. Nas Margens do Tempo_IS Km 23".

5 Fragmento do documentário em <http://vimeo.com/32621992> com o título "Evandro Carlos Jardim. Nas Margens do Tempo_Cultura". 


\section{Considerações finais}

Talvez um trabalho desta natureza nos permita resgatar a presença do narrador, segundo Benjamin (1985) esquecido, seja o narrador viajante que partilha de sua experiência, seja do narrador que conhece profundamente o espaço que habita, alcançando uma profundidade quase mística, expressando-se através das linguagens, da imagem, do gesto, da oralidade. "Não seria sua tarefa trabalhar sobre a matéria prima da experiência - a sua e a dos outros - transformando-a num produto sólido, útil e único?” (Benjamin 1985:221).

Assim definido, o narrador figura entre os mestres e os sábios. Ele sabe dar conselhos: não para alguns casos, como o provérbio, mas para muitos casos, como o sábio. Pois pode recorrer ao acervo de toda uma vida... Seu dom é poder contar a sua vida; sua dignidade é contá-la inteira. (Benjamin 1985:221)

Assim, de modo diverso de uma ficção, o encadeamento do vídeo se deu, não pelas relações espaço temporais, ou pelo desenvolvimento de uma narrativa, mas pela construção do discurso. Buscamos explorar a riqueza da expressão verbal e corporal extraída a partir da proposição de refletir sobre a obra de Evandro Carlos Jardim e seu papel como professor e formador desta geração de artistas.

O conjunto da obra do artista Evandro Carlos Jardim é muito extenso e ainda não é bem conhecido pela sociedade, que ainda está descobrindo a complexidade da sua poética.

Estes conteúdos que buscamos apresentar, colaboraram para que o vídeo adquirisse um caráter mais abstrato. Entretanto, estabelecemos alguns elementos narrativos, compostos pela estrutura básica de roteiros de ficção: apresentação, desenvolvimento e desfecho, para criar um vínculo com o espectador. Para atender a este objetivo e para conferir uma certa dinâmica ao discurso contínuo, lançamos mão da alternância dos tempos, espaços, pessoas, com a apresentação de obras do Evandro, experiências vividas, e apresentação dos espaços que visitamos, preservando uma unidade sustentada pelo encadeamento do discurso.

A partir destas considerações, observamos que seqüências podem cumprir funções diferenciadas, seja para introduzir um filme, ou finalizá-lo; para expressar uma idéia, conceito ou pensamento; para apresentar um personagem, um ambiente; para criar uma experiência sensível; para problematizar; para dar tempo para a reflexão; para criar surpresas; para fisgar a atenção do espectador; para cobrir uma imagem. "O projeto de documentário se forja a cada passo, se debate frente a mil realidades que, na verdade, ele não pode nem negligenciar, nem dominar" (Puccini 2009:127).

Frente à disponibilidade daquele que se expõe em um documentário, o realizador deve assumir um compromisso ético com o universo abordado, a questão ética deve prevalecer às questões estilísticas. Mesmo que autorizada, a utilização da imagem de alguém, como já dissemos, apresenta suas fragilidades, assim como sua força expressiva, trata-se de algo delicado que deve sempre ser considerado.

Coutinho (Bragança 2008) aponta para uma relação de poder que se investe o portador da câmera. De fato a câmera tem o poder de registrar, como dissemos, as falhas e as fissuras da realidade, onde estamos todos incluídos. Deste modo o realizador deve estar consciente de seu papel ético. 
Por todas as considerações aqui colocadas, concluímos que o documentário, longe de fácil, é muito exigente, implica em grande responsabilidade e todas as escolhas realizadas no calor da hora, afinal, ficam permanentemente impressas no produto final. Seja em suas presenças ou ausências.

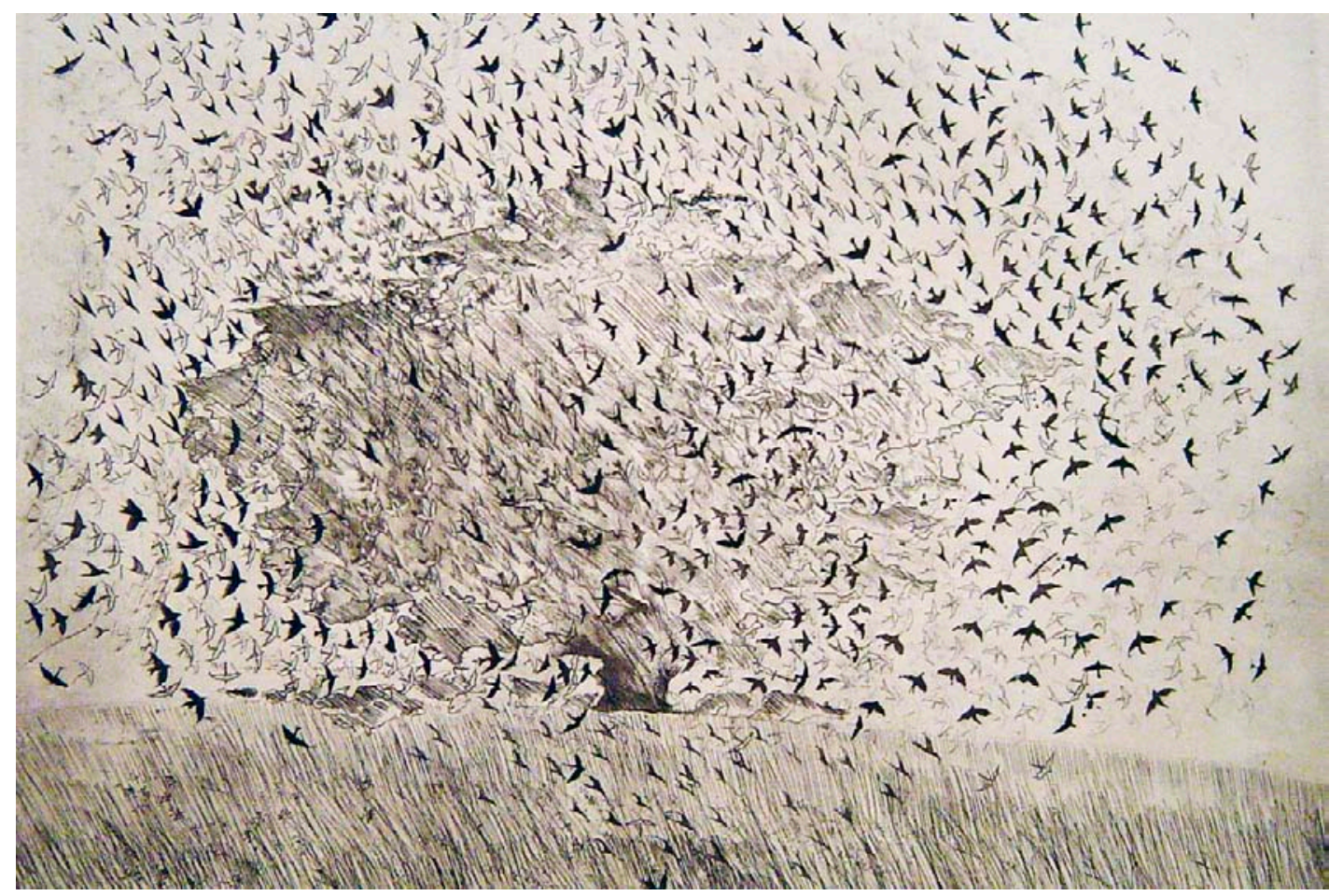

Figura 5: Figuras I.S. Km 23, sobre o vôo dos pássaros comuns, 1980/1981, Água forte e água tinta sobre papel, $45 \times 54,9 \mathrm{~cm}$.

\section{ReferênCias Bibliográficas}

Aumont, Jacques. 2004. O Olho interminável \{Cinema e Pintura\}. São Paulo. São Paulo. Brasil. Cosac\&Naify.

Benjamin, Walter. 1985. Obras escolbidas, magia e técnica, arte e política. Vol 1. São Paulo. São Paulo. Brasil. Ed. Brasiliense.

Brissac Peixoto, Nelson. 1996. Paisagens Urbanas. São Paulo. São Paulo. Brasil. SENAC. Ed. Marca d'Água.

Bragança, Felipe (org). 2008. Eduardo Coutinho. Rio de Janeiro. Rio de Janeiro. Brasil. Ed. Beco do Azougue.

Cole, Ariane. 2007. "A arte do documentário: notas sobre o audiovisual, a antropologia visual e o processo de criação.” in Antropologia Visual e Hipermídia. Editado por José da Silva Ribeiro e Sérgio Bairon. Porto. Portugal. Ed. Afrontamento.

Dubois, Philippe. 2004. Cinema, Video e Godard. Trad. Mateus Araújo Silva. Brasil. . São Paulo. São Paulo. Cosac\&Naify.

Macambira, Ivoty. 1998. Evandro Carlos Jardim. São Paulo. São Paulo. Brasil. Edusp.

Mubarac, Cláudio. 2005. O desen ho estampado: a obra gráfica de Evandro Carlos Jardim. São Paulo. São Paulo. Brasil. Pinacoteca do Estado de São Paulo. 
Nichols, Bill. 2005. Introdução ao documentário. Trad. Mônica Saddy Martins. São Paulo. Campinas. Brasil. Papirus.

Ostrower, Fayga. 1990. “Acasos e criação artística”. Rio de Janeiro. Rio de Janeiro. Brasil. Ed. Campus.

Puccini, Sérgio. 2009. Roteiro de documentário. Da pré-produção à pós-produção. Campinas.

Brasil. Papirus.

Ribeiro, José da Silva. 2004. Antropologia Visual: da minúcia ao olhar distanciado. Biblioteca das Ciências Sociais. Porto. Portugal. Edições Afrontamento.

Salles, Cecília Almeida. O Gesto Inacabado; processo de criação artística. Rio de Janeiro. Rio de Janeiro. Brasil. FAPESP. Annablume. 1998.

Xavier, Ismail (Org). 1983. A experiência do cinema: antologia. Brasil. Edições Graal.

Embrafilme.

\section{AUTEUR MOVIE AND MULTIDIMENSIONAL FILM SCRIPT IN DOCUMENTARY PRODUCTION The article analysis the production process of the documentary "Evandro Carlos Jardim, Over the Margins of Time" which portraits the work of Evandro Carlos Jardim, a Brazilian artist and engraver, who looks back onto 50 years of work as both an artist and a teacher. The complexity of his work poses various questions in regard to the way his work can be approached by audiovisual language, like the representation of space and time and the beings and objects attached to it, the narrative, the gesture, the text, the music and the poetry of his works. We attempt in this way to reflect on his artistic vision and the formal, ethic and aesthetic choices involved in his work.}

Keywords: documentary film, art, visual language, film script. 